\title{
Biodegradation of pyridine using aerobic granules in the presence of phenol
}

\author{
Sunil S. Adav ${ }^{a}$, Duu-Jong Lee ${ }^{a, *}$, N.Q. Ren ${ }^{b}$ \\ ${ }^{a}$ Department of Chemical Engineering, National Taiwan University, Taipei 10617, Taiwan \\ ${ }^{\mathrm{b}}$ School of Environmental and Municipal Engineering, Harbin Institute of Technology, Harbin 150090, China
}

\section{A R T I C L E I N F O}

Article history:

Received 21 January 2007

Received in revised form

11 March 2007

Accepted 30 March 2007

Available online 17 May 2007

Keywords:

Aerobic granule

Pyridine

Phenol

Inhibition

Kinetics

\begin{abstract}
A B S T R A C T
Aerobic granules cultivated with $500 \mathrm{mg} / \mathrm{L}$ phenol medium effectively degraded pyridine at a concentration of $250-2500 \mathrm{mg} / \mathrm{L}$; maximum degradation rate was $73.0 \mathrm{mg}$ pyridine $\mathrm{g} / \mathrm{VSS} / \mathrm{h}$ at $250 \mathrm{mg} / \mathrm{L}$ pyridine concentration. Phenol concentrations of $500-2000 \mathrm{mg} / \mathrm{L}$ limited pyridine degradation in a competitive inhibition pattern, as interpreted using MichaelisMenten kinetics with corresponding parameters $V_{\max }, K_{m}$ and $K_{I}$ of $63.7 \mathrm{mg} / \mathrm{L} \mathrm{h}^{-1}, 827.8$ and $1388.9 \mathrm{mg} / \mathrm{L}$, respectively. Fluorescent staining and confocal laser scanning microscopy (CLSM) tests suggested that an active biomass accumulated at the granule outer layer. Denaturing gradient gel electrophoresis (DGGE) fingerprint profile demonstrated that dominating microbial strains exist in phenol and pyridine-degrading aerobic granules.
\end{abstract}

(c) 2007 Elsevier Ltd. All rights reserved.

\section{Introduction}

Pyridine and its derivatives are by-products of coal gasification (Stuermer et al., 1982) and retorting oil shale (Leenheer et al., 1982), and are utilized as a catalyst in the pharmaceutical industry. Technologies for removing pyridine from wastewater are biodegradation (Sandhya et al., 2002; Rhee et al., 1996; Lee et al., 1991, 1994, 2001), adsorption (Akita and Takeuchi, 1993; Sabah and Celik, 2002; Yokoi et al., 2002), adsorption and electrosorption (Niu and Conway, 2002), ozonation (Stern et al., 1997), and ion exchange (Akita and Takeuchi, 1993).

Aerobic granules have been employed in treating highstrength wastewaters containing organic compounds (Moy et al., 2002), nitrogen and phosphorus (Yang et al., 2003), and phenol (Jiang et al., 2002, 2004). Tay et al. (2004) showed that their granules degraded phenol at a specific rate $>1 \mathrm{~g}$ phenol/ $\mathrm{g} / \mathrm{VSS} / \mathrm{d}$ at a phenol concentration of $500 \mathrm{mg} / \mathrm{L}$. Adav et al. $(2007 a, b)$ isolated strains in aerobic granules with high phenol-degrading capability. Other recent works on aerobic granule processes include Nancharaiah et al. (2006a,b), de Kreuk et al. (2005), and Su and Yu (2005, 2006a, b).

This work examines the feasibility of using a cultivated phenol-fed granule to degrade pyridine in water, and discusses the possible inhibition effects of phenol during pyridine degradation. The strains in aerobic granules corresponding to pyridine and phenol degradation were identified.

\section{Materials and methods}

\subsection{Granule cultivation}

Aerobic granules were cultivated in a column-type sequential aerobic sludge reactor. The reactor was seeded with activated sludge and phenol as the sole carbon source

*Corresponding author. Tel.:+886 2 26325632; fax:+886 223623040.

E-mail address: djlee@ntu.edu.tw (D.-J. Lee).

0043-1354/\$ - see front matter (c) 2007 Elsevier Ltd. All rights reserved.

doi:10.1016/j.watres.2007.03.038 
using synthetic wastewater with the following composition: $1000 \mathrm{mg} / \mathrm{L}\left(\mathrm{NH}_{4}\right)_{2} \mathrm{SO}_{4} ; 200 \mathrm{mg} / \mathrm{L} \mathrm{MgCl} ; 100 \mathrm{mg} / \mathrm{L} \mathrm{NaCl} ; 20 \mathrm{mg} / \mathrm{L}$ $\mathrm{FeCl}_{3} ; 10 \mathrm{mg} / \mathrm{L} \mathrm{CaCl}{ }_{2}$; and, phosphate buffer $(1350 \mathrm{mg} / \mathrm{L}$ $\mathrm{KH}_{2} \mathrm{PO}_{4}, 1650 \mathrm{mg} / \mathrm{L} \mathrm{K}_{2} \mathrm{HPO}_{4}$ ). The synthetic wastewater also had the following micronutrients $(\mathrm{g} / \mathrm{L}): \mathrm{H}_{3} \mathrm{BO}_{3}, 0.05 ; \mathrm{ZnCl}_{2}$, 0.05; $\mathrm{CuCl}_{2}, 0.03 ; \mathrm{MnSO}_{4} \cdot \mathrm{H}_{2} \mathrm{O}\left(\mathrm{NH}_{4}\right)_{6}, 0.05 ; \mathrm{Mo}_{7} \mathrm{O}_{24} \cdot 4 \mathrm{H}_{2} \mathrm{O}, 0.05$; $\mathrm{AlCl}_{3}, 0.05 ; \mathrm{CoCl}_{2} \cdot 6 \mathrm{H}_{2} \mathrm{O}, 0.05$; and $\mathrm{NiCl}, 0.05$ (Moy et al., 2002). The medium was sterilized by autoclaving for $15 \mathrm{~min}$ at $121^{\circ} \mathrm{C}$. The phenol solution was filter-sterilized and added to the autoclaved medium. The reactor was operated in $12 \mathrm{~h}$ cycles. Air bubbles for aeration were supplied through the base of the reactor. The granules formed and matured at $\mathrm{pH}$ 6.8 over 3 weeks.

\subsection{Degradation test}

Four parallel batch tests were performed. In test batch I, the synthetic wastewater containing pyridine (the sole source of carbon) at $250-3000 \mathrm{mg} / \mathrm{L}$ concentrations were added into the batch reactors. The experiment was initiated by inoculating equal volumes of aerobic granules.

In test batch II, the medium with 500 or $1000 \mathrm{mg} / \mathrm{L}$ pyridine was mixed with phenol as the carbon source at concentrations of $0-2000 \mathrm{mg} / \mathrm{L}$. A constant volume of granules $(4 \mathrm{~mL})$ was added to the reactors.

In test batch III, the medium with $1000 \mathrm{mg} / \mathrm{L}$ phenol was mixed with pyridine at concentrations of $0-1500 \mathrm{mg} / \mathrm{L}$. Equal volumes of granules were added to each reactor.

To identify the inhibition mechanism, the biomass in all reactors in test batch IV was kept constant with pyridine concentrations of $200-1000 \mathrm{mg} / \mathrm{L}$ with or without 250 and $500 \mathrm{mg} / \mathrm{L}$ phenol.

Air was supplied to each reactor at a rate of $1 \mathrm{~L} / \mathrm{min}$. Liquid samples were collected at $3 \mathrm{~h}$ intervals. To estimate the stripping loss of pyridine (and phenol) by airflow during tests, an identical reactor operated with the same synthetic wastewater and without granules was used as a control. Maximum stripping rate was $1.2 \mathrm{mg}$ pyridine/L/h, which was insignificant throughout the test period $(27 \mathrm{~h})$. To minimize the stripping effects, condensers were equipped on all reactors to recover the stripped pyridine (and phenol). All experiments were performed in duplicate to assess data reproducibility.

Subsequently, adsorption was studied at various initial concentrations (ranging from 200 to $800 \mathrm{mg} / \mathrm{L}$ ). The experiments were performed in serum bottles containing $50 \mathrm{~mL}$ solution and $2.5 \mathrm{~g}$ (wet weight) granules in rotary shaker at $100 \mathrm{rpm}$ and samples were analyzed for residual pyridine at $2 \mathrm{~h}$ intervals for $18 \mathrm{~h}$. The pyridine and phenol are the substrates for the active biomass hence the active biomass was heat-killed by heating the granules at $75^{\circ} \mathrm{C}$ for $2 \mathrm{~h}$. This method did not affect the physical integrity of the granules (Hawari and Mulligan, 2006; Nancharaiah et al. 2006a, b). The difference between uranium (VI) biosorption onto live biomass $(51.03 \mathrm{mgU} / \mathrm{gm}$ dry wt.) and heatkilled biomass (48.2 $\mathrm{mgU} / \mathrm{gm}$ dry wt.) was not significant (Nancharaiah et al., 2006a, b). The maximum adsorption rate was $0.11 \mathrm{mg}$ pyridine/L/h, which was negligible throughout the test-period.

\subsection{Analytical methods}

The dry weight of granules and volatile suspended solids (VSS) in the suspension were measured according to Standard Methods (APHA, 1998). Pyridine concentrations in the reactor were determined via high-performance liquid chromatography (HPLC) equipped with a C18 column (Varian, Inc., CA, USA), and measured spectrographically at $254 \mathrm{~nm}$. The mobile phase consisted of acetonitrile:water (300:700), $0.11 \mathrm{~g}$ heptane sulphonic acid, $0.29 \mathrm{~g}$ anhydrous sodium acetate, and $2.5 \mathrm{~mL}$ glacial acetic acid. The concentration of phenol was measured spectrographically at $276 \mathrm{~nm}$.

\subsection{Granule staining and CLSM imaging}

The collected granules were maintained fully hydrated during staining. Fluoresceinisothiocyanate (FITC), an amine reactive dye, was utilized to stain proteins and amino-sugars in cells and the extracellular polymeric substances (EPS). The SYTO 63, which is a cell-wall-permeable nucleic acid stain, was applied to analyze cells. The SYTOX blue, a cell-wallimpermeable stain, was utilized to stain dead cells in the granules. Concanavalin tetramethylrhodamine conjugate (ConA) was used to bind to $\alpha$-mannopyranosyl and $\alpha$-glucopyranosyl sugar residues. Nile red was utilized to stain lipids. Calcofluor white was utilized to stain $\beta$-polysaccharides. All probes were purchased from Molecular Probes (Carlsbad, CA, USA).

Confocal laser scanning microscopy (CLSM) (Leica TCS SP2 Confocal Spectral Microscope Imaging System, Gmbh, Germany) was utilized to visualize cell distributions in aerobic granules. The granules were imaged using a $10 \times$ objective and analyzed with Leica confocal software. The fluorescence of SYTO 63 was detected via excitation at $633 \mathrm{~nm}$ and emission at $650-700 \mathrm{~nm}$. The fluorescent intensity of SYTOX blue was analyzed via excitation at $458 \mathrm{~nm}$ and emission at 460-500 $\mathrm{nm}$. The fluorescence of Nile red, FITC, and Calcofluor white were detected via excitation at 514,448 , and $400 \mathrm{~nm}$ and emission at 625-700, 500-550, and 410-480 $\mathrm{nm}$, respectively. Staining details are available in Chen et al. (2007).

\subsection{DNA isolation and DGGE}

The DNA extraction method from aerobic granules is available in Adav et al. (2007a). Polymerase chain reaction (PCR) amplification of the $16 \mathrm{~S}$ ribosomal DNA (16S rDNA) gene was performed using extracted DNA with forward primer P1 and reverse primer $\mathrm{P} 2$ as described by Muyzer et al. (1993). The GCrich sequence of 40 nucleotides (GC clamp) was attached at $5^{\prime}$ end of primer P1.

Denaturing gradient gel electrophoresis (DGGE) tests were conducted utilizing the Bio-Rad universal mutation detection system with $10 \%(\mathrm{w} / \mathrm{v})$ polyacrylamide gels. The range of denaturants $(100 \%$ denaturant corresponds to $7 \mathrm{M}$ urea and $40 \%$ (v/v) deionized formamide) was 35-65\%. Electrophoresis was performed at $60^{\circ} \mathrm{C}$ for $12 \mathrm{~h}$ at $120 \mathrm{~V}$. Gels were stained with ethidium bromide and photographed using a UV transilluminator. 


\section{Results}

\subsection{Granule characteristics}

The pyridine-degrading granules were compact bioaggregates comprising many bacterial strains (Fig. 1). After degrading $1000 \mathrm{mg} / \mathrm{L}$ pyridine, filamentous bacteria were identified at the granule surface (Fig. 1b) together with a large diversity of microbial morphotypes including rods and cocci (Fig. 1c). No detectable changes in surface morphology of granules were observed for fresh phenol-cultivated granules and pyridinedegrading granules.

\subsection{Pyridine biodegradation test}

The aerobic granules efficiently degraded pyridine over initial concentrations of $200-2500 \mathrm{mg} / \mathrm{L}$ (Fig. 2). At initial pyridine concentrations of 250 and $500 \mathrm{mg} / \mathrm{L}$, degradation kinetics followed closely a zero-order kinetics with no time delay. The specific degradation rate of pyridine was 73.0 and $66.8 \mathrm{mg}$ pyridine/g/VSS/h at 250 and $500 \mathrm{mg} / \mathrm{L}$ of pyridine, respectively. A time lag was noticeable in tests with 2000 and $2500 \mathrm{mg} / \mathrm{L}$ pyridine, in which pyridine was completely degraded at 80 and $110 \mathrm{~h}$, respectively. The corresponding specific degradation rate declined to $31.0 \mathrm{mg}$ pyridine/g/VSS/h at $2500 \mathrm{mg} / \mathrm{L}$ pyridine. At $\geqslant 3000 \mathrm{mg} / \mathrm{L}$ pyridine, the rate of pyridine degradation was low, implying a strong inhibitory effect of pyridine on the granules.

\subsection{Degradation of pyridine with phenol}

Fig. 3 presents pyridine degradation curves with different initial concentrations of phenol. Compared with the control (pure pyridine test), the speed of pyridine degradation was slower, whereas the magnitude of reduction increased as the phenol concentration increased. For example, $12 \mathrm{~h}$ was required to completely degrade $500 \mathrm{mg} / \mathrm{L}$ pyridine, whereas $18 \mathrm{~h}$ was needed to degrade the same amount of pyridine in the presence of $2000 \mathrm{mg} / \mathrm{L}$ phenol, and $26 \mathrm{~h}$ was required to completely degrade $1000 \mathrm{mg} / \mathrm{L}$ pyridine. In the presence of $2000 \mathrm{mg} / \mathrm{L}$ phenol, lag time was approximately $10 \mathrm{~h}$; complete degradation was achieved at $>42 \mathrm{~h}$.

Fig. 4 shows the phenol degradation curves with different initial concentrations of pyridine. Phenol degraded faster than pyridine in pure substrate tests. When both substrates co-existed in the medium, the phenol degradation rate was slightly slower than that of the control; however, the rate of

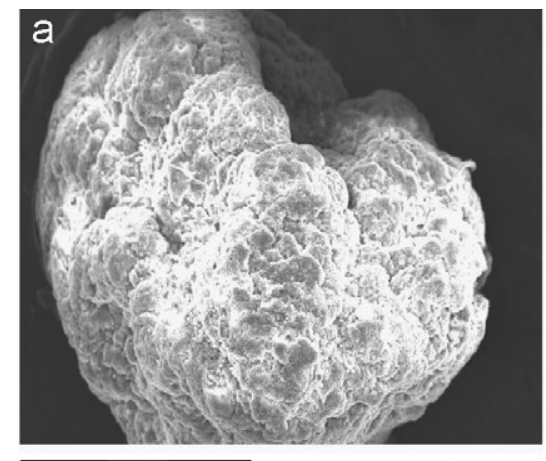

$300 \mu \mathrm{m}$

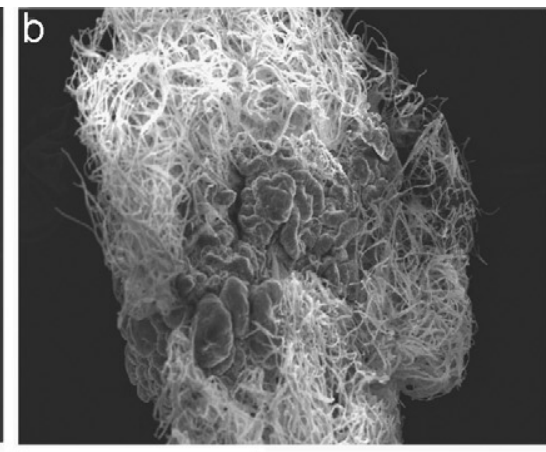

$400 \mu \mathrm{m}$

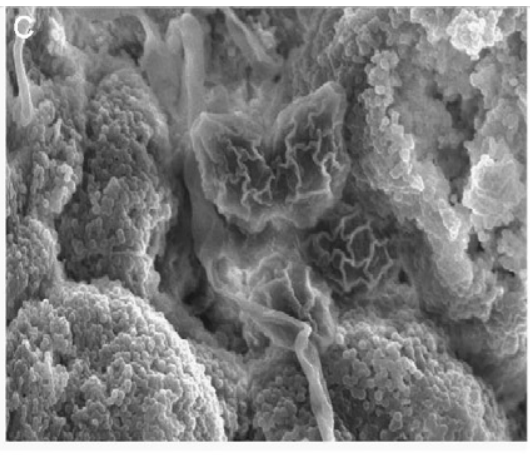

$300 \mu \mathrm{m}$

Fig. 1 - Scanning electron micrographs of pyridine-degrading granules.
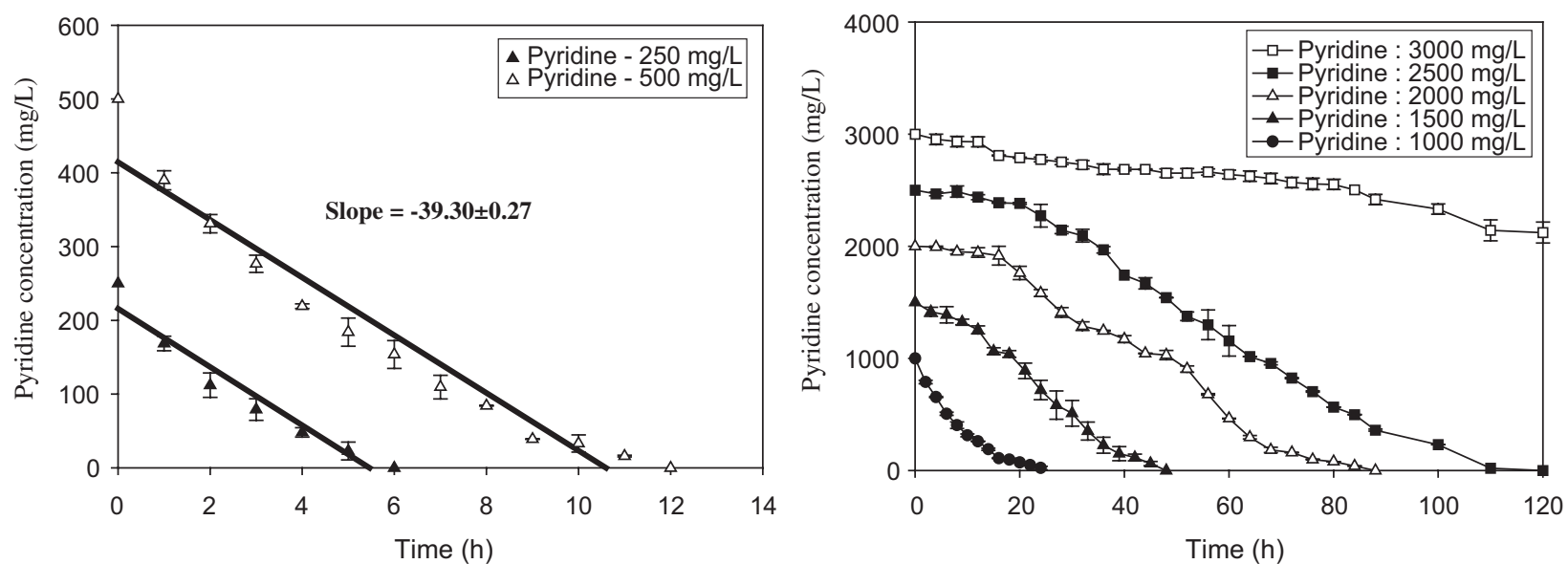

Fig. 2 - Batch tests of phenol-degrading granules with different initial pyridine concentrations. 
a

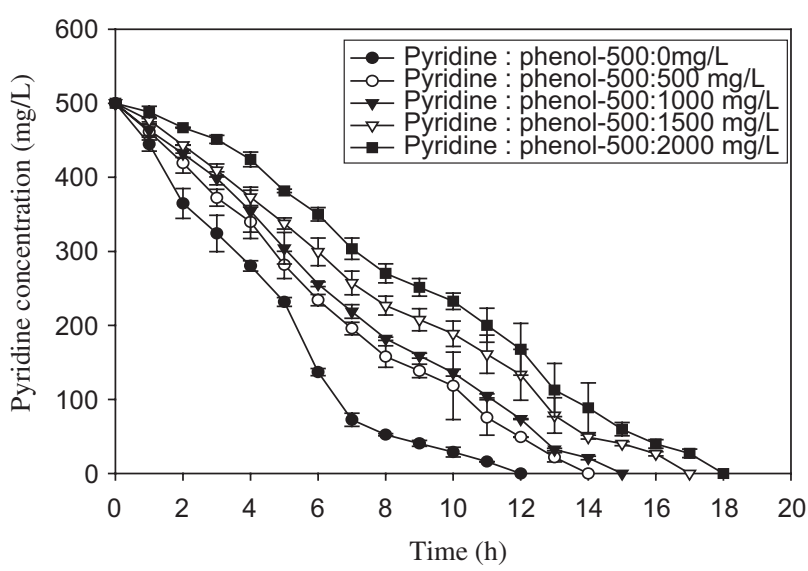

b

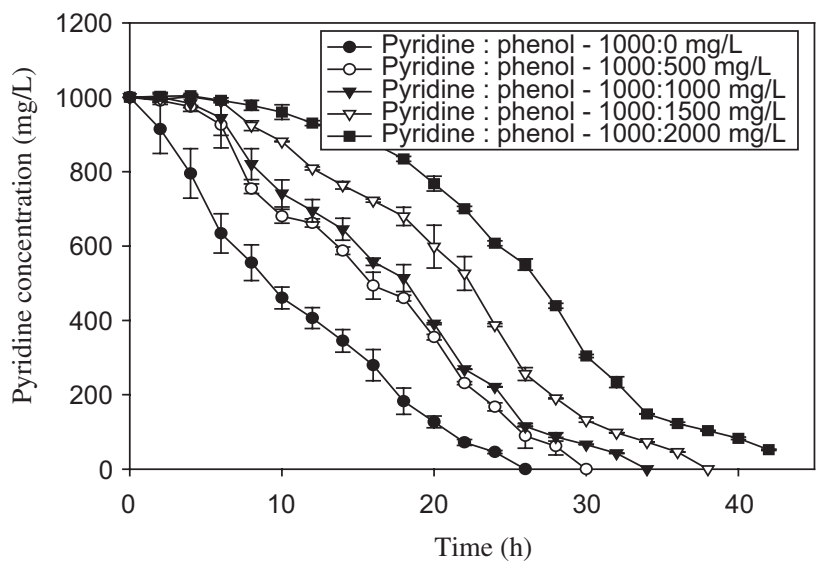

Fig. 3 - Influence of different initial phenol concentrations on pyridine degradation.

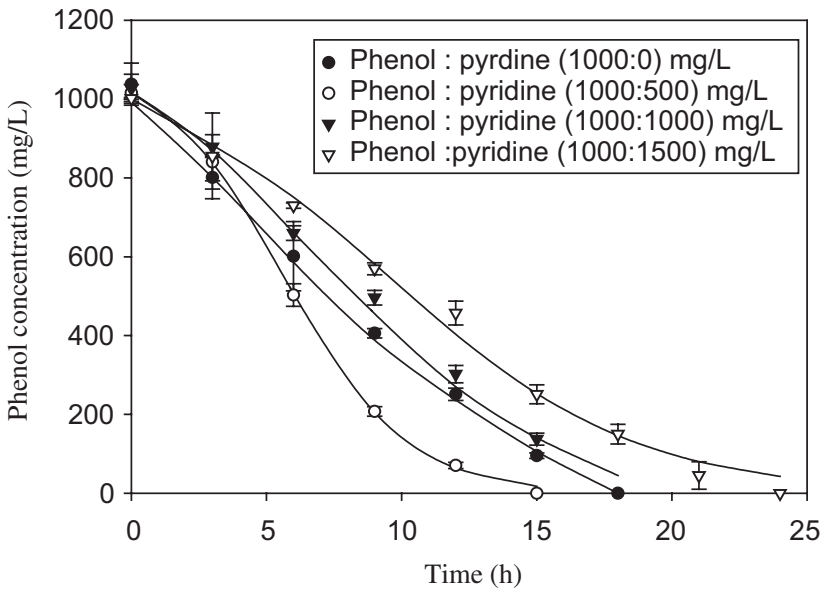

Fig. 4 - Influence of different initial pyridine concentrations on phenol degradation.

Table 1 - Comparison of pyridine and phenol degradation rates by aerobic granules

\begin{tabular}{|c|c|c|}
\hline $\begin{array}{l}\text { Concentration } \\
\text { (pyridine:phenol, } \\
\text { mg/L) }\end{array}$ & $\begin{array}{c}\text { Rate of degradation } \\
\text { (mg } \\
\text { pyridine }\left(\mathrm{g}^{-1} \mathrm{VSS}^{-1}\right)\end{array}$ & $\begin{array}{l}\text { One- } \\
\text { way } \\
\text { ANOVA }\end{array}$ \\
\hline 500:0 (control) & $66.9 \pm 0.1$ & - \\
\hline $500: 500$ & $57.5 \pm 0.7^{* *}$ & $p=0.002$ \\
\hline $500: 1000$ & $54.6 \pm 1.5^{* *}$ & $p=0.006$ \\
\hline $500: 1500$ & $47.6 \pm 1.9^{* * *}$ & $p=0.001$ \\
\hline $500: 2000$ & $44.7 \pm 1.6^{* * *}$ & $p<0.001$ \\
\hline 1000:0 (control) & $58.5 \pm 0.1$ & - \\
\hline $1000: 500$ & $51.3 \pm 1.1^{* *}$ & $p=0.005$ \\
\hline 1000:1000 & $45.2 \pm 2.8^{* * *}$ & $p<0.001$ \\
\hline $1000: 1500$ & $40.3 \pm 1.6^{* * *}$ & $p<0.001$ \\
\hline $1000: 2000$ & $36.6 \pm 4.8^{* * *}$ & $p<0.001$ \\
\hline
\end{tabular}

pyridine degradation was largely suppressed. Hence, pyridine has minimal effect on phenol degradation though the opposite is not true.

\section{Discussion}

\subsection{Co-degradation of phenol and pyridine}

Phenol limited the degradation rates for pyridine via granules (Fig. 3), as satisfactory statistics performed by ANOVA $(p<0.001)$ (Table 1).

Pyridine reaction rates with and without $250 \mathrm{mg} / \mathrm{L}$ phenol were determined at a constant granule mass $(1.59 \pm 0.05 \mathrm{~g} / \mathrm{VSS} / \mathrm{L})$. The Lineweaver-Burk plot demonstrated a competitive inhibition (Fig. 5). Restated, phenol competed with pyridine for the same enzyme site; however, the formed enzyme-phenol complex could not generate its endproduct in the reaction. The specific enzyme for pyridine degradation was present in the system that has a high affinity for phenol. Thus, phenol granules could be applied for the removal of phenol in the presence of pyridine in industrial wastewater.

The Michaelis-Menten kinetics in the presence of a competitive inhibitor was stated as follows:

$\mathrm{V}_{0}=\frac{\mathrm{V}_{\max }[\mathrm{S}]}{\alpha \mathrm{K}_{\mathrm{m}}+[\mathrm{S}]}$,

where $\alpha=1+[\mathrm{I}] / \mathrm{K}_{\mathrm{I}}, \mathrm{V}_{\max }$ is the maximum reaction velocity, $\mathrm{S}$ the pyridine concentration, $I$ is the phenol concentration, $K_{m}$ is the Michaelis-Menten constant, and $K_{\mathrm{I}}$ is the inhibitory constant. Eq. (1) can be rearranged into the Lineweaver-Burk type equation

$\frac{1}{\mathrm{~V}_{0}}=\frac{\alpha K_{\mathrm{m}}}{\mathrm{V}_{\max }[\mathrm{S}]}+\frac{1}{\mathrm{~V}_{\max }}$.

The $V_{\text {max }}, K_{\mathrm{m}}, \alpha_{1} K_{\mathrm{m}}$ and $\alpha_{2} K_{\mathrm{m}}$ determined from Fig. 5 were $63.7 \mathrm{mg} / \mathrm{L} / \mathrm{h}$, and $827.8,981.8$, and $1381 \mathrm{mg} / \mathrm{L}$, respectively. That is, $\alpha_{1}=1.18$ and $\alpha_{2}=1.67$, and $K_{\mathrm{I}}$ was estimated to be 1389 and $746.3 \mathrm{mg} / \mathrm{L}$. At $250 \mathrm{mg} / \mathrm{L}$ phenol concentration, 


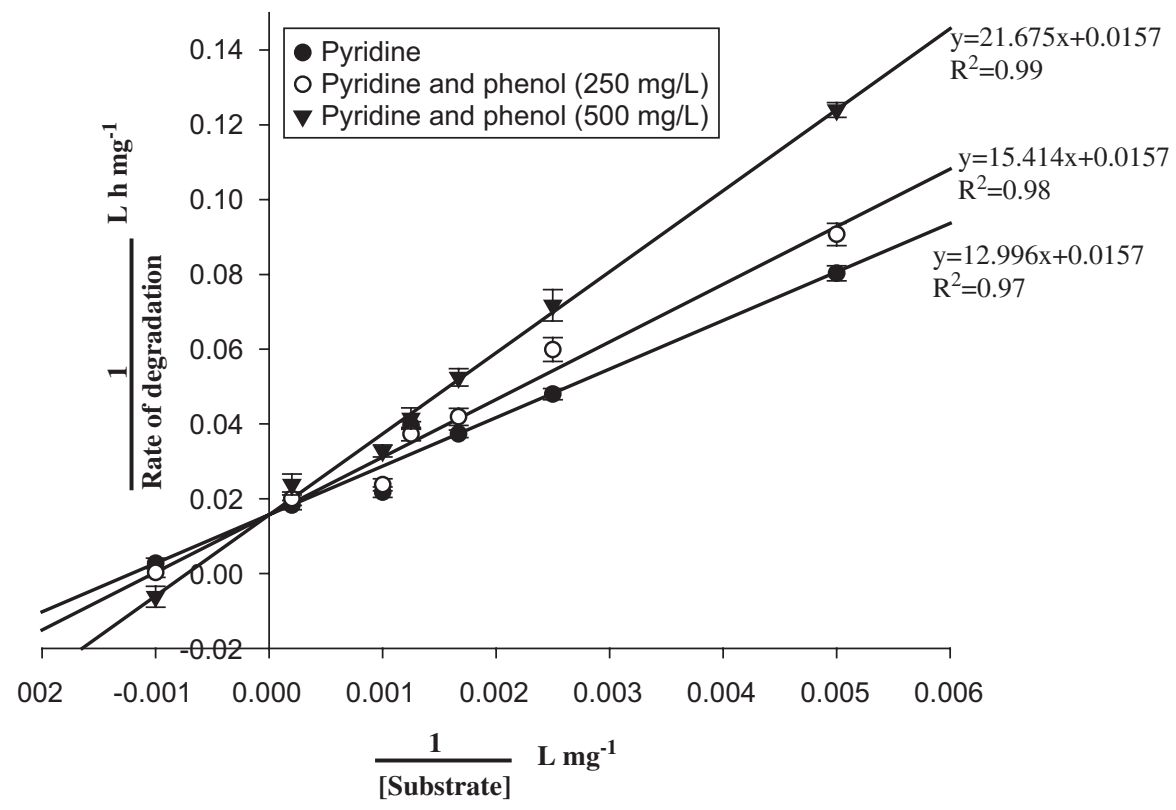

Fig. 5 - Line Lineweaver-Burk plot for bisubstrate reaction.
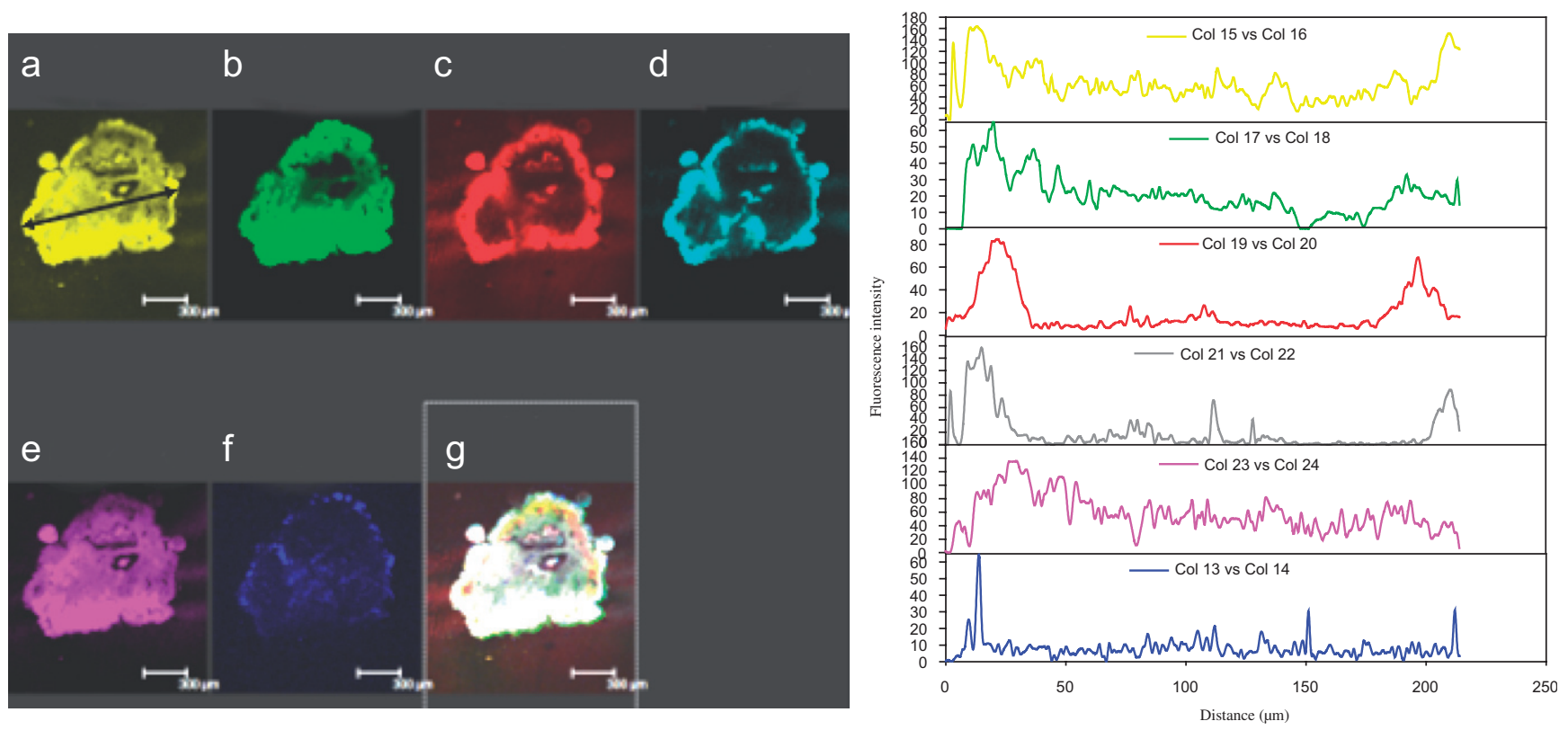

Fig. 6 - CLSM images of pyridine-degrading granule and distribution profiles of extracellular polymeric substances along the line indicated. (Distance 0 indicates surface of granule). Left: (a) lipids (yellow): Nile red; (b) proteins (green): FITC; (c) total cells (red): SYTO 63; (d) $\alpha$-polysaccharide (light blue): Con A rhodamine; (e) dead cells (violet): Sytox blue; (f) $\beta$-polysaccharide (blue): calcofluor white; (g) combined image. Right: fluorescent intensities of six stains.

$K_{I}$ was $29.3 \%$ higher than $K_{m}$, suggesting that the pyridinedegrading enzyme had greater affinity for pyridine than phenol.

Fig. 5 shows a set of double-reciprocal plots, one obtained in the absence of inhibitor and two at different concentrations of a competitive inhibitor. Increasing [I] resulted in a family of lines with a common intercept on the 1/rate of degradation axis but with different slopes. The unchanged value of $V_{\max }$ demonstrated the competitive effect.

\subsection{Granule structure}

Fig. 6 (left panel) presents the CLSM images of stained granules following degradation with $1000 \mathrm{mg} / \mathrm{L}$ pyridine. The fluorescent intensity of proteins (green), lipids (yellow), and dead cells (violet) correlated with each other and accumulated over the complete granule interior. This observation suggests that the proteins and lipids were generally bound to dead cell membranes. The granule outer layer was composed 
of live cells (SYTO 63 in red), $\beta$-polysaccharide (Calcofluor white in blue), and $\alpha$-polysaccharide (Con A in light blue). A bioactive layer located on the granule surface, similar to

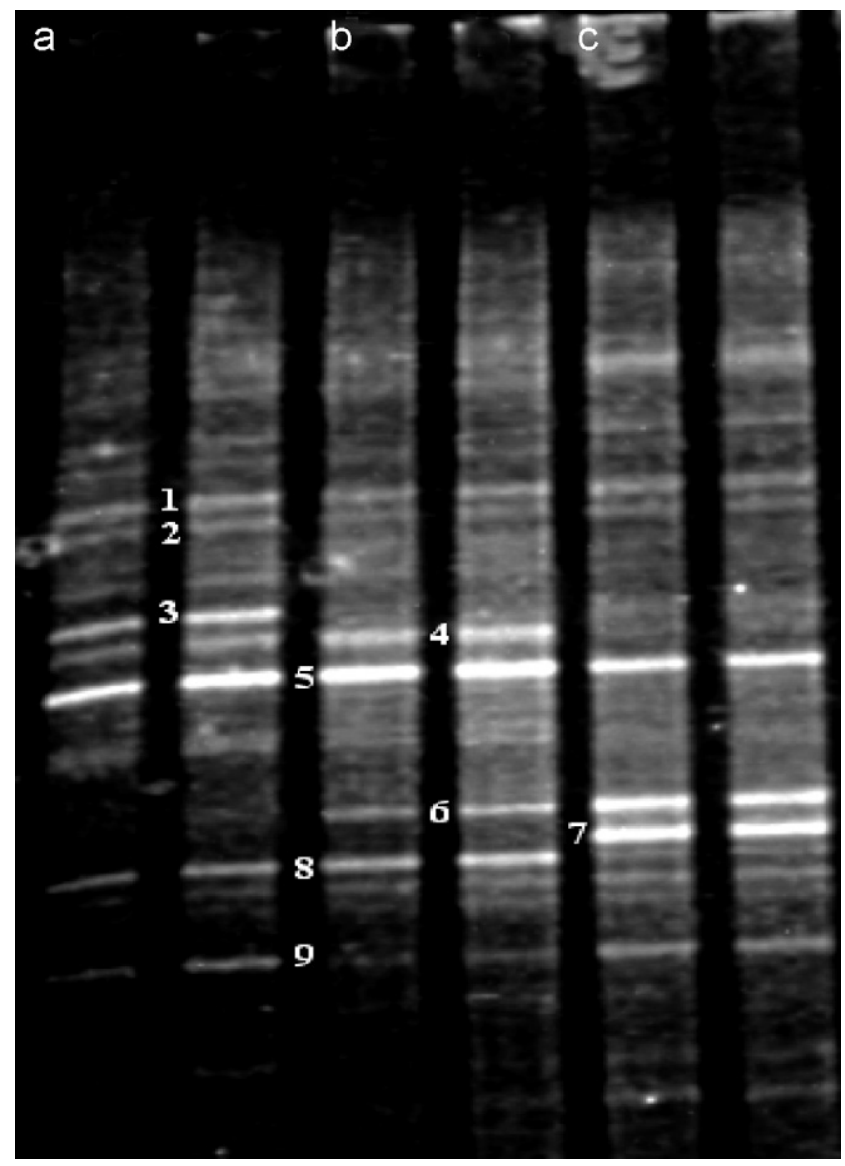

Fig. 7 - Ethidium bromide-stained polyacrylamide denaturing gradient gel with DGGE profiles of 16S rDNA gene fragments after PCR amplification of nucleic acids from (a) phenol granules, (b) pyridine granules, and (c) codegrading phenol and pyridine granules. those observed in phenol-degrading granules (Adav et al., 2007a, b).

Fig. 6 (right panel) presents the intensity distributions of the six stains applied to the granule. Inward from the granule surface is a layer approximately $10 \mu \mathrm{m}$ thick, primarily composed of lipids and $\alpha$-polysaccharides. Under this surface layer exists a layer comprising lipids, proteins, $\alpha$ - and $\beta$-polysaccharides, and live cells $(10-40 \mu \mathrm{m})$. Inside this layer, the non-cellular core was principally composed of proteins, lipids, and dead cell nucleic acids.

All granules analyzed in this work have layered structures in their interiors similar to those shown in Fig. 6 . Hence, only approximately $22 \%$ of the granule mass contained active biomass for phenol/pyridine degradation. The non-cellular core comprising mainly proteins provided the granule with its mechanical strength

\subsection{Microbial analysis}

Fig. 7 represents the DGGE fingerprint profile of PCR amplified sequences for phenol, pyridine, and phenol/pyridine codegrading aerobic granules. The DNA extraction and DGGE experiments were performed twice. An identical DGGE pattern was acquired for replicate samples. Nine bands were excised, amplified and sequenced to identify microbial species (Table 2).

The following strains were identified in granules fed with $2000 \mathrm{mg} / \mathrm{L}$ phenol: Bacillus weihenstephanensis strain RBE1CD (band 1); B. sphaericus strain D45 (band 2); Enterobacter cancerogenus sp. EBD (band 3); B. cereus (band 4); Acinetobacter sp. (band 5); Acinetobacter calcoaceticus strain CBMAI 464 (band 8); and, Pseudomonas sp. Hugh2319 (band 9).

A shift in the microbial community was observed when pyridine was present. When the phenol-fed granules were cultivated in $500 \mathrm{mg} / \mathrm{L}$ pyridine solution for $24 \mathrm{~h}$, the E. cancerogenus sp. EBD strain (band 3) was undetectable in

Table 2 - Sequence analyses of bands derived from 16S rDNA of aerobic granules

\begin{tabular}{|c|c|c|c|c|c|c|c|}
\hline $\begin{array}{l}\text { Band } \\
\text { no. }\end{array}$ & $\begin{array}{l}\text { Most closely related } \\
\text { bacterial sequence }\end{array}$ & $\begin{array}{c}\text { Ref } \\
\text { accession } \\
\text { no. }\end{array}$ & $\begin{array}{l}\text { Similarity } \\
(\%)\end{array}$ & $\begin{array}{c}\text { GenBank } \\
\text { accession no. }\end{array}$ & $\begin{array}{l}\text { Phenol } \\
\text { test }\end{array}$ & $\begin{array}{l}\text { Pyridine } \\
\text { test }\end{array}$ & $\begin{array}{l}\text { Phenol/ } \\
\text { pyridine test }\end{array}$ \\
\hline 1 & $\begin{array}{l}\text { Bacillus weihenstephanensis } \\
\text { strain RBE1CD }\end{array}$ & EF111134 & 99 & EF190020 & O & 0 & O \\
\hline 2 & Bacillus sphaericus strain D45 & DQ923492 & 98 & EF190021 & 0 & 0 & 0 \\
\hline 3 & $\begin{array}{l}\text { Enterobacter cancerogenus sp. } \\
\text { EBD }\end{array}$ & EF011116 & 99 & EF190022 & O & - & - \\
\hline 4 & Bacillus cereus & DQ177461 & 100 & EF190025 & 0 & 0 & - \\
\hline 5 & Acinetobacter sp. & DQ837531 & 100 & EF190029 & 0 & 0 & 0 \\
\hline 6 & Uncultured bacillus sp. & EF072549 & 98 & EF190028 & - & 0 & 0 \\
\hline 7 & $\begin{array}{l}\text { Klebsiella pneumoniae strain } \\
\text { IEDC } 78\end{array}$ & DQ122297 & 97 & EF190024 & - & - & 0 \\
\hline 8 & $\begin{array}{l}\text { Acinetobacter calcoaceticus } \\
\text { strain CBMAI } 464\end{array}$ & DQ250143 & 98 & EF190023 & O & O & - \\
\hline 9 & Pseudomonas sp. Hugh2319 & AB247215 & 97 & EF190026 & O & O & O \\
\hline
\end{tabular}


the granule; however, an uncultured Bacillus strain (band 6) appeared in the pyridine medium.

When $500 \mathrm{mg} / \mathrm{L}$ pyridine combined with $2000 \mathrm{mg} / \mathrm{L}$ phenol was utilized to cultivate granules originally grown in $2000 \mathrm{mg} / \mathrm{L}$ phenol, B. cereus (band 4) was not present in the granule, whereas both uncultured Bacillus sp. (band 6) and Klebsiella pneumoniae strain IEDC 78 (band 7) appeared in the granules.

Among these strains, B. sphaericus, Pseudomonas sp. Hugh2319, and the Actonetobactor sp. have been shown in the literature to have the capability to degrade aromatic compounds (Kaplan and Rosenberg, 1982, Navon-Venezia et al., 1995, Reisfeld et al., 1972). In all three mediums, Acinetobactor sp. was present in a significant quantity, and likely dominated the pyridine-phenol aerobic granule system. The dominating strains in bioactive layers degraded pyridine and phenol with some mass transfer shield provided by the granule surface layer comprised of lipids and $\alpha$-polysaccharides.

\section{Conclusions}

The cultivated phenol-fed aerobic granules could degrade pyridine with zero order kinetics of $73.0 \mathrm{mg}$ pyridine/g/VSS/h at $250 \mathrm{mg} / \mathrm{L}$ pyridine concentration. The pyridine degradation tests suggested that granules completely degraded $250-1500 \mathrm{mg} / \mathrm{L}$ pyridine at a constant rate with no time lag, and with 12 and $15-\mathrm{h}$ time lag at 2000 and $2500 \mathrm{mg} / \mathrm{L}$ pyridine concentration, respectively. Significant effect was noted for pyridine degradation by aerobic granules at concentration $>2500 \mathrm{mg} / \mathrm{L}$ pyridine. The staining-CLSM test revealed that active microorganisms located at the granule surface while protein and some polysaccharide comprised the granule core.

The presence of phenol limited pyridine degradation rates by the granules. On the contrary, pyridine had minimal effect on the granules to degrade pyridine. The double reciprocal Lineweaver-Burk plot showed a competitive type of inhibition for phenol on pyridine degradation. The $V_{\max }, K_{m}$ and $K_{I}$ in the Michaelis-Menten kinetics were estimated as $63.7 \mathrm{mg} / \mathrm{L} / \mathrm{h}$, 827.8 and $1388.9 \mathrm{mg} / \mathrm{L}$, respectively. The DGGE fingerprint pattern identified nine strains in the aerobic granules. Microbes shift in phenol-cultured granules when pyridine was present. The Acinetobactor sp. was expected to dominate the pyridine-phenol aerobic granule system.

\section{R E F E R E N C E S}

Adav, S.S., Chen, M.Y., Lee, D.J., Ren, N.Q., 2007a. Degradation of phenol by aerobic granules and isolated yeast Candida tropicalis. Biotechnol. Bioeng. 96 (5), 844-852.

Adav, S.S., Chen, M.Y., Lee, D.J., Ren, N.Q., 2007b. Degradation of phenol by Acinetobacter strain isolated from aerobic granules, Chemosphere 67 (8), 1566-1572.

Akita, S., Takeuchi, H., 1993. Sorption equilibria of pyridine derivatives in aqueous solution on porous resins and ion exchange resins. J. Chem. Eng. Jpn. 26 (3), 237-241.

APHA, 1998. Standard Methods for the Examination of Water and Wastewater, 20th ed. American Public Health Association, Washington, DC.

Chen, M.Y., Lee, D.J., Tay, J.H., 2007. Distribution of extracellular polymeric substances in aerobic granules. Appl. Microb. Biotechnol. 73, 1463-1469. de Kreuk, M.K., Pronk, M., van Loosdrecht, M.C.M., 2005. Formation of aerobic granules and conversion processes in an aerobic granular sludge reactor at moderate and low temperatures. Water Res. 39 (18), 4476-4484.

Hawari, A.H., Mulligan, C.N., 2006. Biosorption of lead(II), cadmiu$\mathrm{m}(\mathrm{II})$, copper(II) and nickel(II) by anaerobic granular biomass. Bioresour. Technol. 97 (4), 692-700.

Jiang, H.L., Tay, J.H., Tay, S.T.L., 2002. Aggregation of immobilized activated sludge cells into aerobically grown microbial granules for the aerobic biodegradation of phenol. Lett. Appl. Microbiol. 35, 439-445.

Jiang, H.L., Tay, J.H., Tay, S.T.L., 2004. Changes in structure, activity and metabolism of aerobic granules as a microbial response to high phenol loading. Appl. Microbiol. Biotechnol. 63 (5), 602-608.

Kaplan, N., Rosenberg, E., 1982. Exopolysaccharide distribution and bioemusifier production in Acinetobacter BD4 and BD413. Appl. Environ. Microbiol. 44 (6), 1335-1341.

Lee, S.T., Lee, S.B., Park, Y.H., 1991. Characterization of a pyridine degrading branched Gram-positive bacterium isolated from the anoxic zone of an oil shale column. Appl. Microbiol. Biotechnol. 35, 824-829.

Lee, S.T., Rhee, S.K., Lee, G.M., 1994. Biodegradation of pyridine by freely suspended and immobilized Pimelobacter sp. Appl. Microbiol. Biotechnol. 41, 652-657.

Lee, J.J., Rhee, S.K., Lee, S.T., 2001. Degradation of 3-methylpyridine and 3-ethylpyridine by Gordonia nitida LE31. Appl. Environ. Microbiol. 67 (9), 4342-4345.

Leenheer, J.A., Noyes, T.I., Stuber, H.A., 1982. Determination of polar organic solutes in oil-shale retort water. Environ. Sci. Technol. 16 (10), 714-723.

Moy, B.Y.P., Tay, J.H., Toh, S.K., Liu, Y., Tay, S.T.L., 2002. High organic loading influences the physical characteristics of aerobic granules. Lett. Appl. Microbiol. 34, 407-412.

Muyzer, G., De Waal, E.C., Uitterlinden, A.G., 1993. Profiling of complex microbial populations by denaturing gradient gel electrophoresis analysis of polymerase chain reaction-amplified genes coding for $16 \mathrm{~S}$ rRNA. Appl. Environ. Microbiol. 59 (3), 695-700.

Nancharaiah, Y.V., Joshi, H.M., Mohan, T.V.K., Venugopalan, V.P., Narasimhan, S.V., 2006a. Aerobic granular biomass: a novel biomaterial for efficient uranium removal. Curr. Sci. 91 (4), 503-509.

Nancharaiah, Y.V., Schwarzenbeck, N., Mohan, T.V.K., Narasimhan, S.V., Wilderer, P.A., Yenugopalan, V.P., 2006b. Biodegradation of nitrilotriacetic acid (NTA) and ferric-NTA complex by aerobic microbial granules. Water Res. 40 (8), 1539-1546.

Navon-Venezia, S., Zosim, Z., Gottlieb, A., Legman, R., Carmeli, S., Ron, E.Z., Rosenberg, E., 1995. Alasan, a new bioemulsifier from Acinetobacter radioresistens. Appl. Environ. Microbiol. 61 (9), 3240-3244.

Niu, J., Conway, B.E., 2002. Development of techniques for purification of wastewaters: removal of pyridine from aqueous solution by adsorption at high-area C-cloth electrodes using in situ optical spectrometry. J. Electroanal. Chem. 521 (1-2), 16-28.

Reisfeld, A., Rosenberg, E., Gutnick, D., 1972. Microbial degradation of crude oil: factors affecting the dispersion in sea water by mixed and pure cultures. Appl. Microbiol. 24 (3), 363-368.

Rhee, S.K., Lee, G.M., Lee, S.T., 1996. Influence of a supplementary carbon source on biodegradation of pyridine by freely suspended and immobilized Pimelobacter sp. Appl. Microbiol. Biotechnol. 44, 816-822.

Sabah, E., Celik, M.S., 2002. Interaction of pyridine derivatives with sepiolite. J. Colloid Interface Sci. 251 (1), 33-38.

Sandhya, S., Urn, T.S., Stynarayana, S., Kaul, S.N., 2002. Biodegradation of pyridine from pharmaceutical wastewater. Int. J. Environ. Stud. 5, 1097-1104. 
Stern, M., Elmar, H., Kut, O.M., Hungerbuhler, K., 1997. Removal of substituted pyridines by combined ozonation/fluidized bed biofilm treatment. Water Sci. Technol. 35 (4), 329-335.

Stuermer, D.H., Ng, D.J., Morris, C.J., 1982. Organic contaminants in groundwater near an underground coal gasification site in northeastern Wyoming. Environ. Sci. Technol. 16, 582-587.

Su, K.Z., Yu, H.Q., 2005. Formation and characterization of aerobic granules in a sequencing batch reactor treating soybeanprocessing wastewater. Environ. Sci. Technol. 39 (8), 2818-2827.

$\mathrm{Su}$, K.Z., Yu, H.Q., 2006a. A generalized model for aerobic granulebased sequencing batch reactor. 1 . Model development. Environ. Sci. Technol. 40 (15), 4703-4708.
Su, K.Z., Yu, H.Q., 2006b. A generalized model for aerobic granulebased sequencing batch reactor. 2. Parametric sensitivity and model verification. Environ. Sci. Technol. 40 (15), 4709-4713.

Tay, J.H., Jiang, H.L., Tay, S.T.L., 2004. High-rate biodegradation of phenol by aerobically grown microbial granules. J. Environ. Eng. 130 (12), 1415-1423.

Yang, S.F., Liu, Y., Tay, J.H., 2003. A novel granular sludge sequencing batch reactor for removal of organic and nitrogen from wastewater. J. Biotechnol. 106 (1), 77-86.

Yokoi, Y., Yelken, G., Oumi, Y., Kobayashi, Y., Kubo, M., Miyamoto, A., Komiyama, M., 2002. Monte Carlo simulation of pyridine base adsorption on heulandite (01 0). Appl. Surf. Sci. 188, $377-380$. 